University of Nebraska - Lincoln

DigitalCommons@University of Nebraska - Lincoln

Papers in Veterinary and Biomedical Science

Veterinary and Biomedical Sciences,

Department of

2009

\title{
Swine Immunity and Genetic Resistance to Porcine Reproductive and Respiratory Syndrome Virus (PRRSV) Infection
}

Joan K. Lunney

APDL, BARC, USDA, Beltsville, MD, United States

Derek Petry

University of Nebraska - Lincoln

Rodger Johnson

University of Nebraska - Lincoln, rjohnson5@unl.edu

Daniel Kuhar

APDL, BARC, USDA, Beltsville, MD, United States

Ramon Molina

lowa State University, Ames, IA, United States

See next page for additional authors

Follow this and additional works at: https://digitalcommons.unl.edu/vetscipapers

Part of the Veterinary Medicine Commons

Lunney, Joan K.; Petry, Derek; Johnson, Rodger; Kuhar, Daniel; Molina, Ramon; Christopher-Hennings, Jane; Zimmerman, Jeffrey; and Rowland, R. R. R., "Swine Immunity and Genetic Resistance to Porcine Reproductive and Respiratory Syndrome Virus (PRRSV) Infection" (2009). Papers in Veterinary and Biomedical Science. 102.

https://digitalcommons.unl.edu/vetscipapers/102

This Article is brought to you for free and open access by the Veterinary and Biomedical Sciences, Department of at DigitalCommons@University of Nebraska - Lincoln. It has been accepted for inclusion in Papers in Veterinary and Biomedical Science by an authorized administrator of DigitalCommons@University of Nebraska - Lincoln. 


\section{Authors}

Joan K. Lunney, Derek Petry, Rodger Johnson, Daniel Kuhar, Ramon Molina, Jane Christopher-Hennings, Jeffrey Zimmerman, and R. R. R. Rowland 
Swine immunity and genetic resistance to porcine reproductive and respiratory syndrome virus (PRRSV) infection

Joan K. Lunney ${ }^{1, *}$, Derek Petry ${ }^{2,3}$, Rodger Johnson ${ }^{2}$, Daniel Kuhar ${ }^{1}$, Ramon Molina ${ }^{4}$,

Jane Christopher-Hennings ${ }^{5}$, Jeffrey Zimmerman ${ }^{4}$, R.R.R. Rowland ${ }^{6}$

${ }^{1}$ APDL, BARC, USDA, Beltsville, MD, United States

${ }^{2}$ University of Nebraska, Lincoln, NE, United States

${ }^{3}$ Triumph Foods, United States

${ }^{4}$ Iowa State University, Ames, IA, United States

${ }^{5}$ South Dakota State University, United States

${ }^{6}$ Kansas State University, Manhattan, KS, United States

Keywords: Porcine reproductive and respiratory syndrome; Resistance/susceptibility; Immune gene expression; Cytokine regulation

E-mail address: jlunney@anri.barc.usda.gov (J.K. Lunney).

Species: Swine

Current vaccines are only partially effective against porcine reproductive and respiratory syndrome (PRRS) virus infection because they elicit a weak immune response 
that is not fully protective. PRRS is the most economically significant disease facing the swine industry today, costing U.S. pork producers at least $\$ 560$ million annually. Despite substantial research efforts the exact components of a protective anti-PRRSV immune response are still not known, thus we are testing alternate approaches to evaluate immunity and genetic resistance to PRRSV. We used host genomics to compare different lines of pigs and look for factors that correlated with PRRSV resistance/susceptibility. Viremia, weight change, and rectal temperature at $0,4,7$, and 14 days post-PRRSV infection (dpi) were recorded and genetic differences detected (Petry et al., 2005). We evaluated immune gene expression in RNA from frozen lung and bronchial lymph node (BLN) tissue of the 7 highest and lowest responders per line, and from each of their control littermates, as well as serum cytokine protein levels. Genetic analyses of this data indicated that levels of interleukin-8 (IL8) may be predictive of resistance. Additionally, low (not the expected high) levels of serum interferon-gamma (IFNG) after infection may be associated with a PRRSV resistant phenotype. These data are critical for genetic association studies to fine map candidate genes and determine causative alleles of PRRSV resistance/susceptibility. Further genetic studies are required to affirm these associations. For direct immunity studies we have assessed immune gene expression in lung, BLN, and tonsil samples, and protein expression in serum, collected from pigs infected for over 200 days after PRRSV infection. We compared pigs that apparently cleared the viral infection in the first $28 \mathrm{dpi}$ to pigs that even at 150 dpi have evidence of long term persistent PRRSV infection. Results show that there is up regulation of expression of IFNG associated T helper 1 (Th1) markers from 14 to $84 \mathrm{dpi}$; regulatory IL10 and apoptosis associated markers are also increased early. To date, however, no significant differences between persistent and non-persistent PRRSV infected pigs have been discovered in immune gene expression; serum protein expression studies are underway. We hope to reveal differential protein expression associated with PRRSV clearance. Overall, by combining these diverse approaches, we expect to develop new hypotheses about protective anti-PRRSV responses and to identify novel regulatory pathways that would stimulate PRRSV immunity.

Supported by USDA ARS and NRI PRRS CAP1 funds.

doi:10.1016/j.vetimm.2008.10.026 